\title{
Statistical Analysis of Impact of Non-Oil Tax Revenue on the Nigeria Economy
}

\author{
Olagunju Kehinde J \\ National Bureau of Statistics, Abuja \\ Omotola Adeniyi A \\ Federal School of Statistics, Sasa Ojoo, Ibadan. Oyo state \\ Nuga Kehinde A \\ Federal School of Statistics, Marchok, Kaduna State \\ Phillips Samuel Ademola \\ Federal School of Statistics, Sasa Ojoo, Ibadan. Oyo state
}

\begin{abstract}
The objective of this paper is to explore the impact of Non-oil tax revenue on the economic growth of Nigeria as proxies by the real gross domestic product (RGDP). The ordinary least square (OLS) regression analysis was adopted to explore the relationship between the RGDP (the dependent variable) and (the independent variables), company income tax, (CIT), Custom and Excise Duty, CED, Value added Tax,(VAT), Federal government independent revenue, (FGIR), and Education taxes (ET), heads over the period 1995-2015. Augmented Dickey Fuller unit root test was employed to examine the stationary properties of the series, Johansen co-integration test was applied to determine the long-run relationship among study variables while fully modified ordinary least squares co-integrating regression equation was estimated to determine the impacts of Non -oil tax revenue on RGDP. Granger causality test base on Toda and yamamoto procedure was then applied to determine the direction on causality. The ADF unit root tests indicate that all the variable is integrated of order one, 1(1). The Johansen co-integration test reveals that the variable under are co-integrated and do not wander away from each other A simple hypothesis was formulated in the null form which states that there is no significant relationship between federally collected Non-oil tax revenue and the RGDP in Nigeria. The regression result indicated a very positive and significant relationship. However some of the indicator did not have much significant RGDP as they fell below the level expected. The anomaly was attributed to dysfunctional ties in the income tax system, loopholes in tax laws and inefficient tax administration. Suggestions were made as to strategies to be adopted to improve the system of tax administration and tax policy in other to increase Non-oil tax revenue generation.
\end{abstract}

DOI: $10.7176 / \mathrm{JESD} / 10-6-08$

Publication date:March $31^{\text {st }} 2019$

\section{ACKNOWLEDGEMENTS}

We are very grateful to God Almighty for given us the opportunity to put up this write up, the impact of non -oil revenue to growth of Nigeria economy. We acknowledge the contributions of all those who input one thing or the others to the progress of this paper. We also appreciate all the organizations that provided data in which we carried out our analysis.

\subsection{INTRODUCTION}

\subsection{Background of the Study}

Macroeconomic variables are indicators signaling the current trends in the economy. In order to manage an economy well, Government, like all other experts, must study, analyze, and understand the major variables that determine the current behavior of the economy. Thus government must understand the forces of economic growth. why and when recession or inflation occur, and anticipate these trends, as well as what mixture of policy will be most suitable for curing whatever ills the economy out of the many economic indicators, In this research work we will consider four: real GDP, Company Income Tax, Custom Excise Duty, Value Added Tax, Federal Government Inland Revenue Tax and Education Tax in the Study. Economic growth is a measure of expansion of the economy over time. It is a measure of the annual growth and expansion in size of the economy or a measure of the relative economic Strength/power of a country. Economic growth is measured over time relative to the performance of the economy over the exact same period in the immediate past, such as quarterly, or Annual Bi-Annual or every five or six years basis.

Economic growth enables wage and income earners, manufactures, producers, and even macro economic planners to take appropriate rational pre-emptive action that avoids any negative effect of a major change in the direction of the economy. 
Gross Domestic Product (GDP), is a measurement of the annual productivity of the property and labour of all citizens and foreign residents within the geographic borders of a Country including its foreign territories such as embassies and purchased military bases abroad. When GDP is divided by the GDP deflator index and multiply by 100 the result is called real GDP. Whenever there is increase in real GDP of a country it boosts the overall output and we called it economic growth. The economic growth is helpful to increase the incomes of the society, help the nation to bring the unemployment at low level and also helpful in the deliveries of public services. Over the last few decades the macroeconomic variables and the economic growth relationship became the hot issue amongst researchers, (Ullah and Rauf 2013).

Company income tax (CIT) was introduced in Nigeria in 1961. This law has been amended many times and is currently called the Company Income Tax Act 1990 (CITA). The Federal Inland Revenue Services (FIRS) of the Federal Board of Inland Revenue is empowered to administer this tax. Before 1992, CITA were characterized with increasing tax rates and overburdening of the taxpayers, and this induced negative effects on savings and investment, (Odusola, 2006). However, since 1992, measures have been taken to address these problems. For instance, bonus shared is not to be taxable as dividends; excess profit tax was eliminated in 1991, and the capital transfer tax scrapped in 1996. Tax rates on company profits, payable on trade profits and investment income, fell from 45 per cent during 1970 to 1986 (when SAP was introduced) to 40 per cent between 1987 and 1991, further to 35 per cent for the period 1992-95 and to 30 per cent from 1996 to date. There is, however, a 20 per cent tax concession for certain companies: i.e., those engaged in agricultural production or mining of solid minerals with a maximum turnover of N0.5 million and those in manufacturing or the export promotion sector with a turnover not exceeding N1 million. The rates on capital allowances have been reduced continually to reflect the economic reality of the country, (Odusola, 2006).

Customs and Excise Duties (CED) was introduced in Nigeria around I860 making it the oldest form of modern taxation in Nigeria. It was originally known as import duties, representing taxes on imports charged either as a percentage of the value of imports or as a fixed amount contingent on quantity. Import duties are the country's highest yielding indirect or expenditure tax. Before the introduction of SAP in 1986, custom duties were as high as 300 per cent but currently range between $2-75$ per cent, (odusola, 2006).

Excise duties was introduced in 1962 as an ad valorem tax on the output of manufactured goods, as enforced by the Customs and Excise Acts of 1962 and 1965 and the Customs and Excise Tariff Decree of 1995. The tax is administered by the country's custom services. This tax is applied or reneged at will, as in 1998-2000, for instance, when it was revoked. Since 2001, duties have been abolished on most manufactured goods with the exception of products considered harmful such as bleaching creams, alcohol, spirits and tobacco in order to discourage consumption of such harmful goods. These two duties are now lumped together under the Custom and Excise Management Act of 1958 and called customs and are excise duties and administered by the Nigerian Custom Services (NCS).

Value-added tax (VAT) is a tax levied on the value added that results from each exchange. It is an indirect tax collected from someone other than the person who actually bears the cost of the tax. Valued-added tax (VAT) was introduced in Nigeria in January 1993 through the VAT Act No. 102 of 1993, but its implementation began in January 1994. , the tax was intended to be a "Super Tax" to eradicate completely many other taxes related to goods and services. VAT was then imposed on virtually all goods and services whether produced or rendered in Nigeria or not. Exemptions however, was granted in respect of medical and pharmaceutical products, basic food items, fertilizers, agricultural and veterinary medicine, books and educational items, farming and transport equipments, etc. The Value Added Tax effectively replaced the Sales Tax, which, under the constitution, was supposed to be charged by States and not the Federal Government. Since 1994 VAT has become a major source of revenue for the government. The revenue generated was to be shared 20:80 between the federal and state government: currently it is shared 15:50:35 among the federal, state and local governments. The state's allocation was to be earmarked as 30 per cent for the state of origin, 30 per cent for consumption/destination and 40 per cent for equality of the state. The VAT Act designates the FIRS as the responsible institution for implementing VAT. In practice, the Nigerian Custom Service collects VAT on imports on behalf of FIRS.

Federal Independent Revenue Tax (FGIRT): This is the share of Federal Government from the Federation accounts. And Education Tax (ET): A deduction reduces the amount of your income that is subject to tax, thus generally reducing the amount of tax you may have to pay. These credits provide greater tax savings than a tuition deduction since they reduce your tax bill on a Naira, education tax credits can help offset the costs of education.

\subsection{Statement of the Problem}

The rate of economic growth in Nigeria had been unstable for the past years mainly due to tailing oil prices in the world market and tight government policies. 'Die future growth of the economy in Nigeria is uncertain as the current source of growth is not sustainable: productivity and diversification are still a challenge. There is a potential need for harnessing positive growth in the economy but the main issue is on understanding the macroeconomic variables that drive growth. There is need to establish how macroeconomic indicators like, Company Income Tax, 
Custom Excise Duty, Value Added Tax, Federal Government Inland Revenue Tax and Education Tax can help drive the country's growth. This is critical for policy Makers as they make efforts to diversify the sources of growth and avoid suffering from global Shocks. Knowledge about the impact of macroeconomic variables on growth will assist in the crafting of effective legislation to support this Endeavour.

\subsection{Significance of the Study}

This research work will help us to investigate the Impact of Non-oil Tax revenue on the (GDP) economic growth in Nigeria. It will also add to the existing knowledge about the relationship between Company Income Tax, Custom Excise Duty, Value Added Tax, Federal Government Inland Revenue Tax and Education Tax and the economic growth in Nigeria. It will equally help students, government, policy makers and corporate bodies in areas relating to importance of taxation in the country for economic growth.

The implication of this is not farfetched as research in the field could lead to a proper and more focused policy formulation, which would yield much better results.

\subsection{Aim and Objectives of the Study}

This research work is aimed at investigating the impact of Company Income Tax, Custom Excise Duty, Value Added Tax, Federal Government Inland Revenue Tax and Education Tax on economic growth in Nigeria. Specifically, the study intends to

i Determine the order of Co- integration of the study variables:

ii Investigate the existence of long-run stable relationship among the study variables:

iii Test for Granger causality among study variables.

iv Determine the co-integration/relationship between the Non-oil tax revenue and real Gross domestic product .

\subsection{Scope and Limitations of the Study}

There are many macroeconomic variables or indicators signaling the current trends in and economy. However, this research work centers on the impact of impact Company Income Tax, Custom Excise Duty, Value Added Tax, Federal Government Inland Revenue Tax and Education Tax economic growth in Nigeria from 1995 2015. The data is obtained as secondary data from Central bank of Nigeria (CBN) statistical bulletin 2014, National Bureau of Statistics statistical bulletin 2015, and Federal Inland Revenue Services Journal

\subsection{LITERATURE REVIEW}

\subsection{Concept of Taxation}

Taxation is an instrument employed by the government for generating public funds (Anyaduba, control 2004). It is a required payment imposed by the government on the income, profit or wealth of individuals, group of persons, and corporate organizations. Piana (2003) opines that it is a result of the application of tax rate to a tax base. According to Brautigam (2008) a well-designed tax system can help governments in developing countries prioritize their spending, build stable institutions, and improve democratic accountability. The main purpose of a tax is to enable public sector finance its activities so as to achieve some nation's economic and social goals. It can also be for the purpose of redistribution of wealth to ensure social justice (Ola, 2001). Therefore, taxes can be used as an instrument for achieving both micro and macroeconomic objectives especially in developing countries such as Nigeria. However, Musgrave and Musgrave (2004) comment that the dwindling level of tax revenue generation in the developing countries makes it difficult to use tax as an instrument of fiscal policy for the achievement of economic development. Some governments like Canada, United States, Netherland, and The United Kingdom have substantially influenced their economic development through tax revenue generated from Company Income Tax, Value Added Tax, and Personal Income Tax, and have prospered through tax revenue (Oluba, 2008). In Africa, natural resources such as income from production sharing, royalties, and corporate income tax on oil and mining companies yield the significant portion of tax revenue (Pfister, 2009). The tax sources are the basic and most reliable sources of government revenue because of their certainty and flexibility characteristics. Certainty characteristic implies that collection of taxes from taxpayers is assured, all other things being equal. Tax collection is not affected by the state of the economy; whether the economy is declining, stagnant or growing. Its flexibility makes it possible for the government to adjust the tax system to suit her desired purpose

\subsection{Taxation in Nigeria}

In Nigeria, the tax system dates back to 1904 when the personal income tax was introduced in northern Nigeria before the unification of the country by the colonial masters which was later implemented through the Native Revenue Ordinances to the western and eastern regions in 1917 and 1928, respectively (Odusola, 2006). It was later incorporated into direct taxation ordinance No. 4 of 1940. Subsequent governments and laws have continued to improve on Nigeria's taxation system, for example decree no 21 of 1998 etc.

This study conducted to determine the relationship between Non-oil tax revenue on economic growth. Such 
relationship and proper control of tax policy have created a lot of controversy among the policy maker the tax sources are the basic and most reliable sources of government revenue because of their certainty and flexibility characteristics. Certainty characteristic implies that collection of taxes from taxpayers is assured, all other things being equal. Tax collection is not affected by the state of the economy; whether the economy is declining, stagnant or growing. Its flexibility makes it possible for the government to adjust the tax system to suit her desired purpose.

\subsection{Tax Revenue and Development of the Nigerian Economy}

Worlu and Emeka (2012) examined the impact of Tax Revenue on the economic growth of Nigeria between 1980 and 2007 using its effect on infrastructural development. They reported that tax revenue has direct and indirect relationships with the infrastructural development and the gross domestic product respectively (GDP). . Bukie and Adejumo (2013) examined the effect of tax revenue on economic growth of Nigeria for the period 1970 to 2011, regressing indicators of economic growth (domestic investment, labour force and foreign direct investment) on tax revenue. The result shows that the indicators all have a positive and significant relationship with economic growth in Nigeria. Owolabi and Okwu (2011) examined the contribution of only Value Added Tax (VAT) to Development of Lagos State Economy from 2001 to 2005. The study regressed each development indicator (infrastructural, environmental management, education sector, youth and social welfare, agricultural, healthcare, and transportation) on VAT revenue proceeds generated by Lagos State during the study period. Their finding was that revenue generated from VAT positively contributed to the development of the respective sectors of Lagos State economy during the period studied.

Adereti et al. (2011) extended the study by examining the impact of VAT revenue on economic growth of Nigeria during the period 1994 to 2008 using time series data on the GDP, VAT Revenue, Total Tax Revenue and the total revenue of the federal government. The result of the study was in line with that of Owolabi and Okwu (2011) showing an existence of a positive and significant correlation between VAT Revenue and Gross Domestic Product of Nigeria. Okafor (2012) examined the relationship between federally generated revenue and economic development in Nigeria using Gross Domestic Product (GDP) for the period 1981 to 2007. The result of the study showed a positive and significant relationship between Income Tax Revenue and Economic Development of Nigeria.

Adegbie and Fakile (2011) concentrated on the relationship between Company Income Tax alone and Nigeria Economic Development. Their conclusion based on finding was that there is a significant association between company income tax and economic development of Nigeria.

Ogbonna and Ebimobowei (2012) examined the Impact of Tax Reforms and Economic Growth of Nigeria using relevant descriptive statistics and econometric analysis and concluded that the various test shows that tax reforms is positively and significantly related to economic growth and that tax reforms granger cause economic growth .Among other. This study attempt to contribute to the existing literature and employs more sophisticated statistical tools in examining the relationship between Company Income Tax, Custom Excise Duty, Value Added Tax, Federal Government Inland Revenue Tax and Education Tax on economic growth in Nigeria using more recent data.

Ude and Agodi(2013) employed the co-integration methodology alongside error correlation mechanism to investigate the impact of non-oil revenue on economic growth in Nigeria. The result shown that agriculture revenue, manufacturing revenue and interest rate have significant impact on economic growth in Nigeria. They concluded that non-oil revenue has the potential to unlock economy of Nigeria.

The study of Olurankinse and Fatukasi (2012) seeking to established the impact of non -oil sector on economic growth found out that non-oil revenue had a positive impact on the growth of the Nigeria economy.

\subsection{MATERIALS AND METHODS}

\subsection{Source of Data}

The- data used in this research are annual data on real GDP, Company Income Tax, Custom Excise Duty, Value Added Tax, Federal Government Inland Revenue Tax and Education Tax of Nigeria obtained as secondary data from Central bank of Nigeria (CBN) statistical bulletin 2014, National Bureau of Statistics statistical bulletin 2015

\subsection{Statistical Tools/Models}

The collected data were analyzing using the software E-Views 7.0 Version, Augmented Dick Fuller(ADF) Test is used for test of stationery, Johnson Co-integration Technique, is used to determined long-run relationship, Granger Vector Error Correction Model, is also used for causality and the used was inferential statistics ( regression analysis) at 5\% level of significance. The study uses time series data from 1995-2015

\subsection{Model Specification}

The starting point of the model building for this study is the neo-classical growth model, which is expressed as $\mathrm{Y}=\mathrm{f}\left(\mathrm{X}_{1}, \mathrm{X}_{2}, \mathrm{X}_{3}, \mathrm{X}_{4}, \mathrm{X}_{5}\right)$ 
Where:

$\mathrm{Y}=$ Gross Domestic Product, measuring economic growth.

$\mathrm{X}_{1}=$ Companies income tax,

$\mathrm{X}_{2}=$ Custom and Excise Duties,

$\mathrm{X}_{3}=$ Valued Added tax,

$\mathrm{X}_{4}=$ Federal Government Independent Revenue.

$\mathrm{X}_{5}=$ Educational tax,

The researcher builds a model for the investigation of the impact of the Non-oil sector Tax revenue on the economic performance of the Nigeria from Equation from equation (1) above the models are stated below:

Multiple Co integrating Regression Model Specification

$$
Y=\beta_{O}+\beta_{1} X_{1}+\beta_{2} X_{2}+\beta_{3} X_{3}+\beta_{4} X_{4}+\beta_{5} X_{5}+U_{t}
$$

$\beta_{1}$ to $\beta_{5}=$ Coefficient of the model

$\beta_{\mathrm{o}} \quad=\quad$ Intercept of the mode

$\mathrm{U}_{\mathrm{t}} \quad=\quad$ Level of error margin

The estimated linear form of the model when expressed in its log form can be expressed as:

$\log Y=\alpha_{0}+\beta_{1} \log X_{1}+\beta_{2} \log X_{2}+\beta_{3} \log X_{3}+\beta_{4} \log X_{4}+\beta_{5} \log X_{5}$

Where:

$\alpha_{\mathrm{o}}=$ the autonomous interest

$\beta_{1}$ to $\beta_{5}=$ the coefficients to be estimated

$\mathrm{U}_{t}=$ the stochastic error term

The theoretical expectations about the signs of the coefficients are as follows:

$\beta 0>0, \beta_{1}>0, \beta_{2}>0, \beta_{3}>0, \beta_{4}>0, \beta_{5}>0$.

The researcher expected that the sign of the coefficient of all the Non-oil revenue should be positive. This is because according to the neo-classical theory, an increase in the amount of labour input leads to an increase in the level of output other things being equal. In the similar manner, the sign of the coefficient of domestic investment is expected to be positive. This is because an increase in domestic investment will lead to an increase in the gross domestic produced and hence growth. Meanwhile, the sign of the coefficient of foreign direct investment is expected to be positive. This is because an increase in the flow of foreign investment will lead to an increase in gross domestic product. Lastly, the coefficient of tax revenue is expected to be positive. This is so because; an increase in tax revenue provides the necessary revenue to the government to embark on growth promotion activities. Thus, the higher the revenue collected from taxes, the Higher will be the level of economic activities.

\subsection{Methods of Data Analysis}

\subsubsection{Unit root test}

The unit root or stationarity test was carried out using the Augmented Dickey-Fuller test. (Pesaran and Shin, 1999) The following generic equation is used to check the stationary of the time series data used in the study.

$$
\Delta Y_{t}=\beta_{0}+\beta_{1} t+\delta Y_{t-1}+\alpha \sum_{t-1}^{m} \Delta Y_{t-1}+\varepsilon_{t}
$$

Where $\varepsilon t$ is white noise error term and $\Delta Y_{t-1}=Y_{t-1}-Y_{t-2}$ and $\Delta Y_{t-2}=\Delta Y_{t-2} Y_{t-3}:$ and Where $\partial$ is the coefficient of the lagged Length, $Y_{t-1}$,

In general, $\partial$, the coefficient of the lagged length $Y_{t-1}$ is expected to be negative and the estimated $\mathrm{t}$ - statistic will have a negative sign. Therefore, a large negative $t-$ value is generally an indication of stationarity.

The null hypothesis is $\mathrm{H}_{\mathrm{O}}$ : $\beta_{1}=0$ (i.e., there is a unit root or the time series is non-stationary or it has a stochastic trend).

The alternative hypothesis is $\mathrm{H}_{\mathrm{I}}: \beta_{1} \neq 0$ (i.e., the time series is stationary, possibly around a deterministic trend), Before proceeding to the estimation procedure of cointegration test. (Engle and Granger. 1987).

\subsubsection{Johansen Co integration Test Procedure}

A co-integration test is to be carried out to detect the long-run relationship

$$
\begin{gathered}
\Delta X_{t}=\alpha_{0} X_{1}+\sum_{t-1}^{M} \beta_{1} X_{1} \Delta X_{t \cdot-1} X_{t-1}+\epsilon_{t-1}^{m} \beta Y \Delta Y_{t-1}+\varepsilon_{t} \\
\Delta X_{t}=\alpha_{0} X_{2}+\epsilon_{t-1}^{m} \beta X_{2} \Delta X_{t \cdot-1} X_{t-1}+\epsilon_{t-1}^{m} \beta Y \Delta Y_{t-1}+\varepsilon_{t} \\
\Delta X_{t}=\alpha_{0} X_{3}+\epsilon_{t-1}^{m} \beta X_{3} \Delta X_{t-1} X_{t-1}+\epsilon_{t-1}^{m} \beta Y \Delta Y_{t-1}+\varepsilon_{t}
\end{gathered}
$$




$$
\begin{aligned}
& \Delta X_{t}=\alpha_{0} X_{4}+\epsilon_{t-1}^{m} \beta X_{4} \Delta X_{t-1} X_{t-1}+\epsilon_{t-1}^{m} \beta Y \Delta Y_{t-1}+\varepsilon_{t} \\
& \Delta X_{t}=\alpha_{0} X_{5}+\epsilon_{t-1}^{m} \beta X_{5} \Delta X_{t-1} X_{t-1}+\epsilon_{t-1}^{m} \beta Y \Delta Y_{t-1}+\varepsilon_{t}
\end{aligned}
$$

Here $\Delta$ is the first difference operator. The $\mathrm{F}$ test is used to determine whether a long run relationship exists between the variables through testing the significance of the lagged levels of the variables. When a long run relationship exists between the variables, the $\mathrm{F}$ test indicates which variable should be normalized. The null hypothesis of no co-integration is that Trace Statistics value does not greater Critical value Here $\Delta$ is the first difference operator. The $\mathrm{F}$ test is used to determine whether a long run relationship exists between the variables through testing the significance of the lagged levels of the variables. When a long run relationship exists between the variables, the $\mathrm{F}$ test indicates which variable should be normalized. The null hypothesis of no co-integration is that Trace Statistics value does not greater Critical value

\subsubsection{Granger causality test}

Granger causality test was applied in this study as a means of ascertaining causality among the variables. By definition (Granger, 1980), an economic series $X_{t}$ is said to granger cause $Y_{t}$ if changes in $X_{t}$ must precede changes in $Y_{t}$ based on the axiom that the past and present may cause the future but the future cannot cause the past. Basically Granger measures precedence and information content.

$$
\begin{gathered}
Y_{t}=a_{0}+a_{1} Y_{t-1}+\ldots . .+a_{p} Y_{t-p}+b_{1} X_{t-1}+\ldots . .+b_{p} X_{t-p}+u_{t} \\
X_{t}=c_{0}+c_{1} X_{t-1}+\ldots . .+c_{p} X_{t-p}+d_{1} Y_{t-1}+\ldots . .+d_{p} Y_{t-p}+v_{t}
\end{gathered}
$$

The test checks the following pairs of hypotheses: $Y$ " Granger causes "' $\mathrm{X}_{t}$, if $y_{2},=0$ in equation (11) Against $X_{\Gamma}$ "Granger causes" $Y, \partial_{u}=0$ in equation (12)

Some of the mentioned tools for the are briefly discussed here, fully modified least square (FM-OLS) regression was originally designed in work by Phillips and Hansen (1990) to provide optimal estimates of cointegrating regression. It accounts for serial correlation effects and for the endogeneity in the regressors those results from the existence of a co-integrating relationship.

Johanson co-integration test is a procedure for testing cointegration of several way $\mathrm{k}$, i(1) time series, this test permit more than one cointegrating relationship.

An augmented Dickey -fuller test tests the null hypothesis that a unit root is present in a times series sample. The alternative hypothesis is different depending on which version of the test is used, but is usually stationarity or trend - stationarity.

\subsection{RESULTS}

\subsection{Results and Discussion}

In this chapter, we are going to present data, analysis and test the hypothesis relating to this study. The data were sourced from National Bureau of Statistics and Central Bank of Nigeria Statistical bulletin, 2014. The collected data were analyzing using software E-Views 7.0 Version for regression analysis at $5 \%$ level of significance.

The first step is to test the unit root of the variables in their log form and below is the result.

Table 4.1.1: Unit root test result

\begin{tabular}{lccc}
\hline Augmented Dickey-Fuller (ADF) Test & & & \\
\hline Variables & Critical Value & Test Statistic & \multicolumn{1}{c}{ Status } \\
\hline Real gross domestic product & -3.0521 & -7.353656 & $1(1)$ \\
Corporate Income Tax & -3.0521 & -4.031539 & $\mathrm{I}(1)$ \\
Customs \& Excise Duties & -3.0521 & -4.034685 & $2(1)$ \\
Value-Added Tax & -3.0521 & -4.436637 & $1(1)$ \\
Federal Government Independent Revenue & -3.0400 & -3.157796 & $1(1)$ \\
Educational Tax & -3.0400 & -3.250600 & $1(1)$ \\
\hline
\end{tabular}

Note **, Significant at 5\%.

Table 4.1.1 Above Reference equation (5) and it hypothesis The unit root test result indicates that the real Gross Domestic (RGDP), Company Income Tax (CIT), Customs \& Excise Duties (CED), Value-Added Tax (VAT), Federal Government Independent Revenue (FGIR) and Educational Tax (ET) in levels reject the null hypothesis of non stationary at the 5\% Levels of significant Mackinnon (1988) critical value. This implies that they are integrated of order one and two i.e. 1(1) and 2(1). and the estimated $t$ - statistic have a negative sign Which implied, a large negative t- value is generally an indication of stationarity. These results are consistent with previous literature that found most of the time series variables stationary and mean reverting. Having established this, we proceed to establish if the time variables could be used for long run Prediction The result of the Johansen co integration test is presented in Table 4.1.2 below: 
Table 4.1.2: Result of Johansen co integration analysis

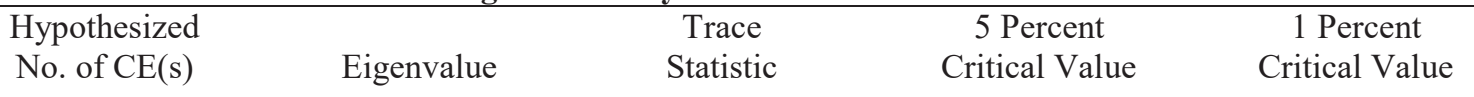

\begin{tabular}{|c|c|c|c|c|}
\hline None $* *$ & 0.981389 & 180.6169 & 94.15 & 103.18 \\
\hline At most $1 * *$ & 0.934364 & 104.9203 & 68.52 & 76.07 \\
\hline At most $2 *$ & 0.772204 & 53.17137 & 47.21 & 54.46 \\
\hline At most 3 & 0.561928 & 25.0646 & 29.68 & 35.65 \\
\hline At most 4 & 0.342668 & 9.382525 & 15.41 & 20.04 \\
\hline At most 5 & 0.071561 & 1.410771 & 3.76 & 6.65 \\
\hline \multicolumn{5}{|c|}{$*(* *)$ denotes rejection of the hypothesis at the $5 \%(1 \%)$ level } \\
\hline Hypothesized & & Max-Eigen & 5 Percent & 1 Percent \\
\hline No. of CE(s) & Eigenvalue & Statistic & Critical Value & Critical Value \\
\hline None $* *$ & 0.981389 & 75.69654 & 39.37 & 45.1 \\
\hline At most $1 * *$ & 0.934364 & 51.74897 & 33.46 & 38.77 \\
\hline At most $2 *$ & 0.772204 & 28.10676 & 27.07 & 32.24 \\
\hline At most 3 & 0.561928 & 15.68208 & 20.97 & 25.52 \\
\hline At most 4 & 0.342668 & 7.971754 & 14.07 & 18.63 \\
\hline At most 5 & 0.071561 & 1.410771 & 3.76 & 6.65 \\
\hline
\end{tabular}

(**) denotes rejection of the hypothesis at the $5 \%(1 \%)$ level

Table 4.1.2 Above indicates two co integration equations at those ranks where the values of the trace statistics exceed the $5 \%$ critical values. This occurred in two places in the table. In addition, this was confirmed by the results of the maximum eigenvalues where co integration exists at ranks where the value of eigenvalues is at least 0.5 . The discovery here is that while the trace statistic result yielded two co integrations, while the max-eigenvalue test Indicated two cointegration. However, theory agrees that co integration exists where there is at least one cointegration.

Table 4.1.3: Result of Granger causality test

\begin{tabular}{lcc}
\hline Null hypothesis $\left(\mathbf{H}_{\mathbf{0}}\right)$ & F-Stat/Prob Value & Conclusion \\
\hline $\mathrm{CIT} \rightarrow$ RGDP & $5.06740(0.02210)$ & \\
$\mathrm{RGDP} \rightarrow$ CIT & $0.13474(0.87506)$ & CIT $\rightarrow$ RGDP \\
$\mathrm{CED} \rightarrow$ RGDP & $2.40558(0.12647)$ & $\mathrm{CED} \rightarrow \mathrm{RGDP}$ \\
$\mathrm{RGDP} \rightarrow$ CED & $0.98274(0.39868)$ & \\
$\mathrm{VAT} \rightarrow$ RGDP & $2.52868(0.11547)$ & VAT $\leftrightarrow$ RGDP \\
$\mathrm{RGDP} \rightarrow$ VAT & $2.21684(0.14575)$ & \\
$\mathrm{FGIR} \rightarrow$ RGDP & $1.11209(0.35625)$ & $\mathrm{RGDP} \rightarrow$ FGIR \\
$\mathrm{RGDP} \rightarrow$ FGIR & $2.13686(0.15492)$ & \\
$\mathrm{ET} \rightarrow \mathrm{RGDP}$ & $0.94793(0.41106)$ & $\mathrm{RGDP} \rightarrow$ ET \\
$\mathrm{RGDP} \rightarrow$ ET & $2.29452(0.13744)$ & \\
\hline
\end{tabular}

Note: $* * *, * * *$ implies $1 \%, 5 \%$ and $10 \%$ significant level

Table 4.1.3 above at lag 2, the result indicates that a uni-directional causality relationship runs from Company Income Tax to economic growth (RGDP). Also, another unidirectional causality relationship runs from Customs \& Excise Duties to economic growth (RGDP). a uni-directional causality relationship runs from Federal Government Independent Revenue Tax to economic growth (RGDP),Also a uni-directional causality relationship runs from Educational Tax to economic growth (RGDP). Also Bi-directional causality relationship runs from Value-Added Tax to economic growth (RGDP). By definition (Granger, 1980), an economic series $\mathrm{X}_{\mathrm{t}}$ is said to granger cause $\mathrm{Y}$ if changes in $\mathrm{X}_{\mathrm{t}}$ must precede changes in $\mathrm{Y}_{\mathrm{t}}$ based on the axiom that the past and present may cause the future but the future cannot cause the past. Basically Granger measures precedence and information content 
Table 4.1.4: Regression between rGDP and Non-oil tax Revenue

\begin{tabular}{lllll}
\hline Variable & Coefficient & Std. Error & t-Statistic & Prob. \\
\hline \hline RGDP $_{\text {t-2 }}$ & 0.405301 & 0.132811 & 3.051719 & 0.0086 \\
LOGCIT & 1.760114 & 2.18562 & 0.805316 & 0.4341 \\
LOGCED & 5.156259 & 2.054782 & 2.509395 & 0.025 \\
LOGVAT & 0.038244 & 1.308778 & 0.029221 & 0.9771 \\
LOGFGIR & 2.166721 & 0.692294 & 3.129768 & 0.0074 \\
LOGET & 1.069501 & 1.539769 & 0.694586 & 0.4987 \\
$\mathrm{C}$ & 8.622928 & 5.603324 & 1.538895 & 0.1461 \\
\hline \hline R-squared & 0.745996 & Mean dependent var & 5.47381 \\
Adjusted R-squared & 0.637137 & S.D. dependent var & 1.262658 \\
S.E. of regression & 0.760601 & Akaike info criterion & 2.551786 \\
Sum squared resid & 8.099198 & Schwarz criterion & 2.89996 \\
Log likelihood & -19.79376 & F-statistic & 6.852872 \\
Durbin-Watson stat & 2.292647 & Prob(F-statistic) & 0.001487 \\
\hline \hline
\end{tabular}

Model:

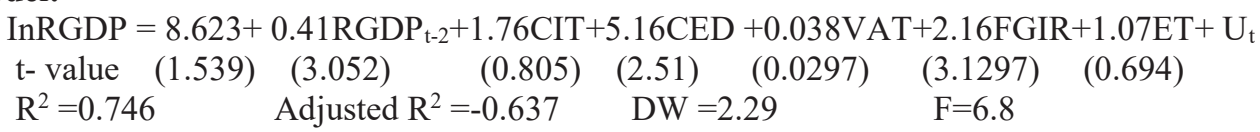

\subsection{Analysis of Results}

Table 4.2.4 The empirical results of the estimated model above is analyzed using three criteria, namely economic apriori criteria, statistical criteria and econometric criteria.

Economic apriori criteria: The estimated regression line has a positive intercept, real gross domestic products will still increase by 8.622928 .

The result also shows that there is a positive relationship between (CIT, CED, VAT, FGIR, ET) and economic grow. This is consistent with the apriori expectation indicating that an increase in any of the Non-oil tax revenue by 1 billion naira will lead to an increase in economic growth (RGDP) by 0.41 billion naira, other things being equal. The result also shows that there is a positive relationship between (CIT, CED, VAT, FGIR, ET) and economic grow in Nigeria. This is consistent with the theoretical postulation, implying that a billion naira increase in any of this variable(CIT, CED, VAT, FGIR, ET) will lead to an increase in economic growth by ( 1.76 , $5.16,0.038,2.16$, and 0.107 ) billion naira This is positively related to economic growth in line with the neo-classical growth model. This means that a thousand increase in labour force will lead to an increase in economic growth

\section{Statistical Criteria}

This study employs the standard normal test i.e. ( $\mathrm{t}$ - Test) because the sample size is less than 30 . The $\mathrm{t}-$ test is computed at 5\% level of significance and at 5\% level of significance, the $t$ - statistic table value is 1.73 . This value is then compared with the calculated value in the result obtained. If the calculated value is greater than the critical value at 5\% level of significance, then the particular parameter estimate is statistically significant and vice versa. From the results obtained, three explanatory variables are statistically significant at $5 \%$ level of significance. These variables include (RGDP CED, FGIR). The statistical significance of these variables is that their $\mathrm{t}$-statistic values calculated for RGDP (3.052), CED (2.51) and FGIR, (3.1297) are all greater than the critical value of 1.729 at $5 \%$ level of significance. This means that these variables are significant in explaining short-run and long run variations in economic growth in Nigeria. On the other hand CIT (0.805), VAT (0.0297), ET (0.0694) is not statistically significant. This is because t- statistic value (1.729) calculated is less than the critical value (1.729) at 5\% level of significance. This shows that the variable is less significant in influencing economic growth in Nigeria during the reference period.

Adjusted R - Squared of 0.746 shows that about 74 percent of the systematic variations in the dependent variable (GDP) has been explained by variations in the independent variables (CIT, CED, VAT, FGIR, ET) The 26 percent left unexplained is due to changes in other variables not captured in the model but represented by the disturbance term. The high value of adjusted $\mathrm{R}-$ Squared $64 \%$ shows that the estimated regression model has a good fit on the data. Similarly, the high value of F - Statistics (6.85) shows that the overall model is statistically significant at $5 \%$ level of significance. This means that there exists a high degree of linear relationship between the dependent variable and the independent variables in the model. From the result obtained, the D - W value of (2.29) falls in the shaded region, representing the region of no serial autocorrelation. Thus, it can be concluded that there is no autocorrelation among the variables in the model. Hence, the model can be employed for policy formulation in the Nigerian economy in the short - run and long- run. 


\subsection{Summary of Findings}

The objective of this study was to examine the Impact of Non-oil tax revenue on (RGDP) economic growth in Nigeria. From the results obtained, the following summary of findings are highlighted

$i$ The result showed that there is a positive relationship between all the Non-Oil tax revenue tax revenue and (RGDP) economic growth in Nigeria. However, the variables are statistically significant in influencing economic growth in Nigeria except (CIT, VAT and ET) that are not statistically significant

ii. The high value of adjusted $\mathrm{R}^{2}$ showed that the estimated regression line has a good fit on the data and that the estimated model has high expandability power.

iii. In the same vein, the high value of F - Square showed that the overall model is statistically significant. This also means that there is a high linear relationship between the dependent variable and the explanatory variable in the model.

vi. Econometric test conducted using the Durbin - Watson statistic showed that there is no autocorrelation in the model. The model therefore can be used for policy formulation in the Nigeria economy.

\section{CONCLUSION}

This study critically analyzes the impact of non-oil tax revenue on Nigerian economy, from the periods 1995 to 2015. It is generally asserted that tax is a major source of government revenue all over the world because the Impact on economic growth revenue from Non -oil tax revenue aids the government in carrying out its responsibilities. However, the role of taxation in Promoting economic growth in Nigeria has not been significantly felt due largely to its poor administration.

The result obtained shows that Non-oil tax revenue has positive effect on economic growth in Nigeria. It is important that efficient and effective tax policy be implemented to ensure that enough revenue is generated for growth purposes.

From the empirical findings of this study policy options are recommended to enhance a stable rate of Gross Domestic Product in an economy like Nigeria, all efforts should be geared by the government towards checking the downwards reduction of revenue caused by the falls in the international price crude oil. Such efforts should include industrialization policy, improved investment climate, consistency in government policies, and political stability among others. This will eventually help to reduce capital flight and encourage both domestic and foreign investment thereby increasing the tax base of the nation. From the studies carried out by it is generally agreed that non-oil revenue has the potential to unlock of any nation. Also that there is need for diversification from oil tax to other sectors of the economy to encourage the generation of non-oil revenue, it was also said that Nigeria Government should provide the necessary infrastructural facilities like electricity supply to boost the production of goods and services.

\subsection{Policy Recommendations}

Based on the results obtained, the following policy recommendations are made.

i. The positive relationship between Non-oil tax revenue and economic growth calls for efficient tax policy to be formulated and implemented so as it to continue to generate the needed revenue for the government. Also revenue collecting authorities of the government should be made more effective in their operations of collecting revenue for the government. Equally important is the need for the upgrading of revenue collecting technique so as to be able to generate more tax revenue for the government. On Company Income tax, Value Added Tax, and Educational Tax.

ii. The positive and significant effect of Company Income tax on economic growth in Nigeria calls for the implementations of policies that will promote investment in Nigeria. Policies such as reducing the cost of doing business should be implemented. Also basic infrastructures such as steady power supply, functional transport systems and efficient water supply should be provided and made workable

iii. The positive impact of (VAT) force on economic growth equally calls for the implementation of policies which will enhance PAYMENT (VAT) in the country. This can be done through the provision of more technical education and continuous training of Staff and enlistment of the Citizens

iv. Finally, the positive and significant impact of Custom Excise Duty (CED) on economic growth calls for appropriate policies to be adopted so as to attract more foreign investors in the country. The provision of infrastructural facilities and the need to cut down the cost of doing business is a right step in the right direction.

\section{REFERENCES}

Fagbemi. T. O. M. Uadiale and A. O. Noah (2010) "The Ethics of Tax Evasion: Perceptual Evidence from Nigeria", European Journal of Social Sciences, Volume 17, Number 3.

Murkur, G. A. (2001) "Design of Tax and Corruption". Conference paper on "Fighting Corruption: Common Challenges and Shared Experiences"

Azubike, J. U. B., (2009), Challenges of tax authorities, tax payers in the management of tax reform processes. 
Niger, Account. 42 (2): $36-42$

Edame, E. (2008). The Essential of Public Finance and Public Financial Management in Nigeria. Revised 3rd Edition: Calabar,Wusen Press Ltd

Odusola A. (2006). Tax evasion problems in Nigeria. Research Paper

Adegbie, F.F. and A.S. Fakile, 2011 Company income tax and Nigeria economic development.European Journal of Social Sciences, 22(2): 309 - 332.

Anyaduba, J.O., 2004. Partnership taxation in Nigeria. ICAN Student Journal, 9(2): 15 - 17.

Brautigam, D., 2008. Taxation and governance in Africa. AEI online. Available from http://www.aei.org/publication/taxation-and-governance-in-africa [Accessed 27th September, 2015].

Soyode L. and Kajola S.O. (2006) Taxation Principles and Practice in Nigeria. Lagos, SiliconCompany

Ezirim, A.C., C.T. Okeke and O.T. Ebiringa, 2010. Achieving vision 2020 in Nigeria: A review of the economic and karket-oriented business reforms. Journal of Sustainable Development in Africa, 12(4): 58-71.

Federal Government of Nigeria, 2011. Constitution of the federal republic of Nigeria (Third Alteration).

The National Industrial Court. Federal Inland Revenue Service, 2014. Annual summary of collected tax in Nigeria. Available from www.firs.gov.ng.

Global Alliance for Tax Justice, 2015. Position Paper and Recommendations for The Third UN Conference on Financing for Development.

Ihenyen , C.J. and E.G. Mieseigha, 2014. Taxation as an instrument of economic growth (The Nigerian Perspective). Information and Knowledge Management, 4(12): 49 - 53.

Koutsoyiannis, A., 1977. Theory of econometrics. London: The Macmillan Press Ltd.

Ayua. (2014 The Constitution Context for Taxation Abuja.CBN. (2014). Central Bank of Nigeria Annual Economic Report. Abuja.

Federal Inland Revenue Service. (2012). A Comprehensive Tax History of Nigeria. Abuja.

Federal Inland Revenue Service. (2007, December 3). A Comprehensive Tax History of Nigeria.Taxation , p. Saturdcg/ Punch.

Federal Inland Revenue Service. (2009). A Comprehensive Tax History of Nigeria. Abuja.

Federal Inland Revenue Service. (2006). Tax History Chronology. Abuja.

FIRS. (2004-2011). Reforms in the tax system. Abuja: Satari Books Ltd.

Grander, C. (1986). Development in the study of Co-Integration Variables. Oxford Bulletin of Economics Statistic , 48 , pp. 213-228.

Gujarati, D. (2005). Basic Econometrics. India.: Tata McGraw-Hill Publishing Company Limited New Delhi, India.

Ndiyo. (2003). Economic and Management Sciences. South African Journal, vol. 6, no.4,.

John C O. and Suleiman A.S A (2014) Value added Tax and Economic Growth in Nigeria (1994-2011) European Journal of Accounting Auditing and Finance Research Vol.2,No.8, pp.62-69,

Olurankinse, F \& Fatukasi B (2012), Analysis of the impact of non -oil sector on economic growth, Canadian social science $8(4), 244-248$. 
APPENDIX I (RAW DATA) Table 1: Composition of Non-oil Revenue Taxes in Nigeria

\begin{tabular}{|c|c|c|c|c|c|c|}
\hline \multirow[b]{2}{*}{ Year } & \multicolumn{6}{|c|}{ Million Naira } \\
\hline & Real GDP & $\begin{array}{l}\text { Corporate } \\
\text { Tax (CIT) }\end{array}$ & $\begin{array}{l}\text { Customs \& } \\
\text { Excise Duties }\end{array}$ & $\begin{array}{l}\text { Value-Added } \\
\text { Tax (VAT) }\end{array}$ & $\begin{array}{l}\text { FG } \\
\text { Independent } \\
\text { Revenue } \\
\end{array}$ & $\begin{array}{l}\text { Educational } \\
\text { Tax (ET) }\end{array}$ \\
\hline 1995 & $352,646.2$ & $21,878.3$ & $37,364.00$ & $20,761.00$ & $20,436.40$ & $2,548.48$ \\
\hline 1996 & $367,218.1$ & $23,100.0$ & $55,000.00$ & $31,000.00$ & $3,407.00$ & $3,300.00$ \\
\hline 1997 & $377,830.8$ & $27,800.0$ & $63,000.00$ & $34,000.00$ & $8,339.90$ & $2,900.00$ \\
\hline 1998 & $388,468.1$ & $33,300.0$ & $57,383.00$ & $36,857.70$ & $11,431.60$ & $3,200.00$ \\
\hline 1999 & $393,107.2$ & $46,200.0$ & $87,906.90$ & $47,135.80$ & $20,076.50$ & $5,700.00$ \\
\hline 2000 & $412,332.0$ & $53,300.0$ & $101,523.60$ & $58,469.60$ & $38,061.80$ & $8,300.00$ \\
\hline 2001 & $431,783.2$ & $69,400.0$ & $170,557.10$ & $91,757.90$ & $44,405.20$ & $16,200.00$ \\
\hline 2002 & $451,785.7$ & $89,100.0$ & $181,408.20$ & $108,601.00$ & $68,134.50$ & $10,100.00$ \\
\hline 2003 & $495,007.2$ & $114,800.0$ & $195,468.60$ & $136,411.20$ & $54,164.40$ & $9,700.00$ \\
\hline 2004 & $527,576.0$ & $130,800.0$ & $181,400.00$ & $108,800.00$ & $58,100.00$ & $17,100.00$ \\
\hline 2005 & $561,931.4$ & $170,200.0$ & $195,500.00$ & $136,400.00$ & $54,200.00$ & $21,800.00$ \\
\hline 2006 & $595,821.6$ & $246,700.0$ & $217,200.00$ & $158,500.00$ & $59,900.00$ & $28,400.00$ \\
\hline 2007 & $634,251.1$ & $332,400.0$ & $232,300.00$ & $179,100.00$ & $212,100.00$ & $59,600.00$ \\
\hline 2008 & $672,202.6$ & $420,600.0$ & $177,700.00$ & $221,600.00$ & $33,300.00$ & $59,500.00$ \\
\hline 2009 & $718,977.3$ & $600,600.0$ & $297,500.00$ & $468,400.00$ & $73,200.00$ & $139,500.00$ \\
\hline 2010 & $776,332.2$ & $666,060.0$ & $309,200.00$ & $562,600.00$ & $153,600.00$ & $89,180.00$ \\
\hline 2011 & $834,000.8$ & $715,430.0$ & $438,300.00$ & $182,500.00$ & $182,500.00$ & $130,750.00$ \\
\hline 2012 & $888,893.0$ & $846,590.0$ & $474,900.00$ & $206,800.00$ & $206,800.00$ & $188,430.00$ \\
\hline 2013 & $950,114.0$ & $986,000.0$ & $434,000.00$ & $274,000.00$ & $796,000.00$ & $279,358.71$ \\
\hline 2014 & $1,009,239.1$ & $1,207,300.0$ & $566,000.00$ & $295,000.00$ & $794,000.00$ & $189,613.73$ \\
\hline 2015 & $1,072,043.4$ & $1,408,432.9$ & $738,147.47$ & $767,333.43$ & $792,005.03$ & $206,040.23$ \\
\hline
\end{tabular}

Source: Federal Inland Revenue Service (FIRS) and Central Bank of Nigeria

APPENDIX 11 (RAW DATA CATEGORIZED IN TO LOG)

Table 2: Log of Composition of Non-oil Revenue Taxes in Nigeria

\begin{tabular}{|c|c|c|c|c|c|c|}
\hline Year & $\begin{array}{l}\text { Log of } \\
\text { Real GDP }\end{array}$ & $\begin{array}{l}\text { Log of } \\
\text { Corporate } \\
\text { Tax (CIT) }\end{array}$ & $\begin{array}{l}\text { Log of } \\
\text { Customs \& } \\
\text { Excise Duties }\end{array}$ & $\begin{array}{ll}\text { Log } & \text { of } \\
\text { Value- } & \\
\text { Added } & \text { Tax } \\
\text { (VAT) } & \end{array}$ & $\begin{array}{l}\text { Log of FG } \\
\text { Independent } \\
\text { Revenue }\end{array}$ & $\begin{array}{lr}\text { Log } & \text { of } \\
\text { Educational } & \text { Tax } \\
\text { (ET) } & \end{array}$ \\
\hline 1995 & 5.55 & 4.34 & 4.57 & 4.32 & 4.31 & 3.41 \\
\hline 1996 & 5.56 & 4.36 & 4.74 & 4.49 & 3.53 & 3.52 \\
\hline 1997 & 5.58 & 4.44 & 4.80 & 4.53 & 3.92 & 3.46 \\
\hline 1998 & 5.59 & 4.52 & 4.76 & 4.57 & 4.06 & 3.51 \\
\hline 1999 & 5.59 & 4.66 & 4.94 & 4.67 & 4.30 & 3.76 \\
\hline 2000 & 5.62 & 4.73 & 5.01 & 4.77 & 4.58 & 3.92 \\
\hline 2001 & 5.64 & 4.84 & 5.23 & 4.96 & 4.65 & 4.21 \\
\hline 2002 & 5.65 & 4.95 & 5.26 & 5.04 & 4.83 & 4.00 \\
\hline 2003 & 5.69 & 5.06 & 5.29 & 5.13 & 4.73 & 3.99 \\
\hline 2004 & 5.72 & 5.12 & 5.26 & 5.04 & 4.76 & 4.23 \\
\hline 2005 & 5.75 & 5.23 & 5.29 & 5.13 & 4.73 & 4.34 \\
\hline 2006 & 5.78 & 5.39 & 5.34 & 5.20 & 4.78 & 4.45 \\
\hline 2007 & 5.80 & 5.52 & 5.37 & 5.25 & 5.33 & 4.78 \\
\hline 2008 & 5.83 & 5.62 & 5.25 & 5.35 & 4.52 & 4.77 \\
\hline 2009 & 5.86 & 5.78 & 5.47 & 5.67 & 4.86 & 5.14 \\
\hline 2010 & 5.89 & 5.82 & 5.49 & 5.75 & 5.19 & 4.95 \\
\hline 2011 & 5.92 & 5.85 & 5.64 & 5.26 & 5.26 & 5.12 \\
\hline 2012 & 5.95 & 5.93 & 5.68 & 5.32 & 5.32 & 5.28 \\
\hline 2013 & 5.98 & 5.99 & 5.64 & 5.44 & 5.90 & 5.45 \\
\hline 2014 & 6.00 & 6.08 & 5.75 & 5.47 & 5.90 & 5.28 \\
\hline 2015 & 6.03 & 6.15 & 5.87 & 5.88 & 5.90 & 5.31 \\
\hline
\end{tabular}

